\title{
NOTES ON THE CANADIAN REPRESENTATIVES OF BRITISH SPECIES OF BEES.
}

BY F. W. L. SLADEN, APIARIST, DOMINION EXPERIMENTAL FARMS.

Of the twenty-eight genera of bees given in Saunders' Hymenoptera Aculeata of the British Isles," no less than twenty-two occur in Canada. The six absent are small genera belonging to an ill-defined unimportant complex in the Andrena group, several of which may yet be found to exist in Canada when this large genus, full of raw material, has been analyzed. In most of the genera common to both countries, there are many Canadian species which are more or less closely related to British species. The following are a few outstanding examples:

\section{Colletes cunicularia Linn.}

Colletes incerualis Say, by far the largest species of Colletes in Eastern Canada and the only one occurring in spring, is apparently the representative of $C$. cunicularia Linn., also much the largest species and the only spring one found in England. Both are among the earliest bees to appear in spring. Ottawa specimens differ from British in having a much shorter coat, which is generally paler and greyer (less brown), and they have well-developed bands of white felt* on the margin of each segment of the abdomen. These bands in British specimens are scarcely discernible, being composed of fewer, looser hairs, which are dingy. Ottawa specimens are smaller; several females measured averaged in length $13.33 \mathrm{~mm}$; British females $14.00 \mathrm{~mm}$; Ottawa males $11.00 \mathrm{~mm}$; British males $13.25 \mathrm{~mm}$.

\section{Andrena clarkella Kirby.}

Comparison of a male and two females of Andrena bicolor Prov. taken by the writer at Ottawa, and a female from Abitibi, with two males and two females of $A$. clarkella Kirby, taken at Maidstone, Kent, England, and with Saunders' description of this species shows no differences either in structure or colour. Even the tint and extent of the different hair colours in both sexes are identical. The characteristic red and red-haired hind tibiæ and tarsi, and black-haired notum in the female, and the comparative lengths of the antennal joints 3,4 and 5 in both sexes are the same. The Canadian examples however, are a little smaller:--females, average length $12.00 \mathrm{~mm}$; Maidstone females $12.75 \mathrm{~mm}$; Ottawa males $8.75 \mathrm{~mm}$.; Maidstone males $9.75 \mathrm{~mm}$.; and the coat on the thorax and abdomen is much shorter and iess shaggy in the Canadian specimens. In both countries these are early spring becs. The Ottawa females were taken during early willow-bloom on April 25, 1915, about ten days after the snow had gone, and the male on April 27. In England it is taken in early March and has been recorded as early as February 19. It is also widely distributed northwards and uncommon, both in Canada and England.

\section{Andrena wilkella Kirby.}

Andrena vinkleyi Vier. is the same as $A$. wilkella Kirby. I can find no differences in structure or size. Both are abundant in late spring at Ottawa and Dover respectively, and are fond of the same plants; Myosotis, etc. In both, the third antennal joint is shorter than the fourth, a character by which wilkslla

*The word "felt" is used to describe very short, close hair, the individual hairs of which are thicker than ordinary hairs. Felt grades into ordinary hairs. 
is known from its close ally similis $\mathrm{Sm}$. This is a short-haired species in which white felt bands on the abdominal segments are well developed with a corresponding bare area on the disc of the segment.

\section{Osmia fulviventris $\mathrm{L}$.}

Specimens of both sexes of Osmia purpurea $\mathrm{Cr}$. from Ottawa and Toronto agree in every respect, including size, with those of $O$. fulviventris $L$. from Dover. This is, therefore, a parallel case to that of Andrenc wilkella, and it is perhaps worthy of note that the Osmia appears in late spring after most of the other species of its genus have appeared as in the case of $A$. wilkella.

\section{Megachile ligniseca L.}

Comparison of both sexes of Megachile inermis Prov. (M. decipiens Lovell and Cockerell) taken at Ottawa, shows this species to be closely related to $M$. ligniseca L. of Europe. Prominent characters possessed in common by specimens from Dover and from different parts of Canada are the very short, decumbent black hair on the disc of the sixth segment of the abdomen and the large head in the female. But the white felt bands on the margins of the segments of the abdomen, well marked in Canadian specimens are rudimentary in the British specimens. Canadian specimens also differ in having the pollen collecting-brush cream coloured-not reddish, and the body hairs grey and black - not brown, and the coat distinctly shorter. Ottawa specimens are also smaller, average length of Ottawa females $14.33 \mathrm{~mm}$.; Dover females $16.00 \mathrm{~mm}$; Ottawa males $12.61 \mathrm{~mm}$; Dover males $13.88 \mathrm{~mm}$. Specimens have been bred in this country from a rotting piece of an apple tree found by Prof. Arthur Wiiley at McGill College. In England it burrows in wood that is more or less decayed. Most of the other Megachile burrow in the ground.

The same differences, - shorter coat, which is whiter (less brown) with stronger white felt bands, and paler (less red) pollen brush, separate $M$. vidua Sm., a species common all over Canada from $M$. willughbiella Kirby, a species common in England and Northern Europe.

\section{Anthophora furcata $\mathrm{Pz}$.}

This British bee is represented in the American fauna by a bee known by the name of Clisodon terminalis $\mathrm{Cr}$., which occurs in Canada from coast to coast and at least as far north as Cochrane, Ont. and Edmonton, Alta. Friese gives the range of $A$. furcata in Eurasia from Norway to Mongolia and south to Caucasia. Ontario specimens differ from British in both sexes in having a shorter coat-much shorter and scantier on the abdomen of the female and generally less brown but greyer and paler, and the hairs on the abdomen run into dense pale bands on the margins of the segments, taking, in the female the extreme form of narrow bands of white feit, interrupted in the middle. No tendency to white felt bands is noticeable in the specimens from Dover. Saunders even gives this as a character for the species. The white felt bands are also absent in four females from the Pacific Coast, (Agassiz, B. C., Shawnigan Lake, V. I., and Victoria, V. I.) but they may have been rubbed off.

Specimens from Ottawa are distinctly smaller than specimens from Dover, but the females from the Pacific Coast are even larger than British females as shown in the following table, and they probably represent a distinct species or at least a geographical variety to which the name neofurcata is here given. 
7 Ottawa males average length $9.50 \mathrm{~mm}$.

7 Ottawa females average $10.75 \mathrm{~mm}$.

5 Dover males average length $10.70 \mathrm{~mm}$.

5 Dover females average length $12.80 \mathrm{~mm}$.

4 Pacific Coast females average length $14 \mathrm{~mm}$.

In England, Anthophora furcata is very faithful to its food plant, Stachys sylvatica, and the Canadian forms may always be found on Stachys palustris. Saunders notes that it burrows in "dead wood," although other species of the genus burrows in the ground. Attracted by a heap of white sawdust around a decayed but stiıl hard stump near Hull, P. Q., on August 16th, 1913, I found this to be riddled with the burrows of Clisodon terminalis. The exceedingly active females, resembling honey-bees in appearance and size, passed in and out of numerous holes in the stump as frequently as the workers of a strong colony of bumble-bees.

\section{Bombus and Psithyrus.}

These northern genera, so rich in biological material, furnish an interesting contribution to this study. They never develop felt bands but there is a uniform coat of long hair resembling fur.

\section{Bombus borealis Kirby.*}

Bombus borealis Kirby, fairly common and widely distributed in the boreal region of Canada east of the Rocky Mountains has its British representative in $B$. distinguendus Morawitz, the distribution of which, according to Hoffer, extends to Siberia. Here again the pattern and even the tint of the coat, deep greenish yellow with a black band across the thorax, very variable in most species of Bombus, is common to both forms with the unimportant exception of more or less black hair on the last segment of borealis, but the British specimens are larger (average length of females $20 \mathrm{~mm}$. compared to $18 \mathrm{~mm}$. in borealis) and they have a much longer and more uneven coat.

In the Mountains and Pacific Coast region, borealis is replaced by a form, appositus, that is intermediate in size between British distinguendus and borealis, having a coat slightly longer than borealis and the yellow band on the anterior part of the thorax very pale while there are no black hairs on the abdomen. Appositus is evidently still more closely related to distinguendus than is borealis. In both the Old and New Worlds, the queens of all these forms appear later in the spring than those of almost every other species of Bombus. The colonies consist of comparatively few workers, and the young queens and drones are raised early. The period of activity therefore lasts a shorter time than in the case of the other species.

\section{Bombus terrestris $L$.}

One of the commonest and most aggressive species of Bombus in England and the continent of Europe is terrestris $L$. This is represented in Canada from the Atlantic Coast to the Mountains by an equally common and aggressive species, B. terricola. In habits, terricola agrees with terrestris not only in those common to the terrestris group such as biting holes at the bases of flowers, but also in the unique habit that separates terrestris from its close ally in England, lucorum, of continuing to leave its winter quarters in small numbers from the opening tof spring right on until about mid-July when all other species have

*This name has priority over distinguendus. 
ceased to appear, instead of during the shorter and more definite period common to all the other species of Bombus. Terricola has the tip of the abdomen tawny like many terrestris forms. In lucorum forms, however, this remains always white. Terricola, however, has a much wider yellow band on the abdomen than any Old World form of terrestris. In this respect it converges towards other species of Bombus found within its region, fervidus, borealis, etc., Terricola has the coat much shorter than terrestris. It is also smaller, average length of female terricola $18 \mathrm{~mm}$., female terrestris, from Dover, $20 \mathrm{~mm}$.

$B$. terricola is replaced in the Mountains and on the Pacific coast by the closely related occidentalis, a somewhat longer-coated species. I do not think that terricola and occidentalis intergrade because I have taken both forms at Banff, Alta.

\section{Bombus lucorum L.}

Bombus lucorum, above mentioned, is, in Britain and Europe, a small mountain or northern form with a rather long coat. B. moderatus $\mathrm{Cr}$. a species of the terrestris group with colour pattern the same as that of lucorum, is found at Banff, Alta. and in Northern B. C., Yukon Territory, and Alaska. It undoubtedly is a lucorum form. It differs from lucorum only in the somewhat paler tint of its yellow bands. In this respect, it not only follows appositus of the same region, but approaches albocinctus $\mathrm{Sm}$. the lucorum form found in Kamchatka, Siberia, which has these bands white.

\section{Bombus lapponicus Fab.}

Franklin notes the close relation between Bombus melanopygus Nyl., a very long-haired, red-banded species, common in the Mountains and Pacific Coast region and Bombus lapponicus Zett. a species found on the high moors of the north of England and Scotland and in arctic and sub-arctic Europe. Sylvicola Kirby, from Arctic Canada, of which melanopygus is probably a variety, seems identical with lapponicus.

\section{Psithyrus vestalis Fourc.}

Bombus terrestris is preyed upon in England by Psithyrus vestalis Fourc. A vestalis form known as ashtoni $\mathrm{Cr}$. is found throughout the range of $B$. terricola and is probably parasitic on it. Ashtoni is smaller than vestalis and has a shorter and paler coat.

\section{Apis mellifera L.}

The variety of honey-bee native to Britain has an entirely black tegument, dark brown hair and feebly-developed white felt bands on the margins of the segments. 'This variety is native to the whole of Western Europe, and it has been introduced into and has spread through Canada during the last two or three hundred years. It still predominates in the Gulf Region, in the north, and on the Pacific Coast. But in Southern Ontario and on the Prairie, it has been largely replaced by the Italian bee, introduced about fifty years ago from Southern Europe, which has the tegument of the abdomen banded with orange, has paler hair and well-developed white felt bands. This bee is also slightly smaller than the black bee. The honey-bees of the Prairie show great constancy in the strong development of the white felt bands.

CONCLUSIONS.

1. The bee fauna of the boreal zone of America contains a number of species closely related to, and in some cases indistinguishable from those in 
north-western Europe and furnishes evidence of a former land connection with a climate comparable to that of Britain or Ontario, in which these species lived.

2. There are, however, in a number of cases certain more or less pronounced differences in character between the descendants now living in Britain and Canada. As a rule, the Canadian forms are smaller, and they have a shorter, closer, less shaggy coat, the colour of which is not so rich or deep, but paler, more dingy; brown changes to ashy grey or dingy white, and red to orange or cream. Usually in the genera where white felt bands are liable to occur on the abdominal segments, these bands either appear for the first time in Canadian forms, or are better developed, that is to say, are wider and more extensive as well as of a more extreme type, with a corresponding reduction of hair on the disc of the segment. Melanism is less frequent and less pronounced. These differences are so widely spread that they evidently represent a definite principle.

3. Searching for the cause of these differences we fint there is an approach towards the British type of characters on the Pacific Coast and in the north of Canada where the summer climate is cool as in Britain, and they are most departed from in the interior and southern part where it is warm. A good illustration of this, in addition to those already given, is found in Megachile perihirta, Ckll. a species that has no Old World representative. At Lethbridge and in the Kootenays, this species has definite white felt bands on the margins of the abdominal segments and there are no black hairs amongst the pale ones on the apical segment. At Victoria, B. C., the white felt bands are weaker and partly broken, the hairs composing them being longer and less dense, and the whole coat is slightly longer. At Cochrane in Northern Ontario these bands are still weaker and the hair on the apical segment is brack.

All the species of Bombus occurring on the Pacific Coast, in the mountains of B. C. and in the Arctic, have a longer, shaggier coat than those occurring in Ontario. The species of Bombus that has the most southerly range in Canada, B. pennsylvanicus has the shortest coat of all. Species of Bombus in the Shetland Islands are rather larger and have longer, shaggier coats than the same species in Scotland. In Great Britain and in Canada also, not only are the species having longer and shaggier coats more plentiful in the north and west, but the shorter-coated species, if they extend so far, grow longer coats.

For the same or closcly related species, size tends to become as a rule, smaller in the south and interior, but the south-interior contains many species, not found all over, some of which are of giant size.

In Canada, the interior and southern conditions reach their extreme at Medicine Hat, a dry, hot, basin-shaped locality in Southern Alberta. Here the species of Anthophora belonging to the subgenus Amegilla, characterized by an extreme development of the white felt bands and swift flight, are common. Species of Amegilla are numerous in Turkistan, Central Asia. At Medicine Hat species of Halictus, Colletes, Melissodes and Melecta appear that are almost covered with dust-like felt. Amongst the parasitic bees, Coelioxys ribis Ckll. is common throughout Canada. In Southern Alberta is found a small form of this species known as grindelice Ckll. (average length of female $10.33 \mathrm{~mm}$. compared with $11.66 \mathrm{~mm}$. of ribis). In grindelice not only are the white felt bands on the abdomen much wider, but the face is largely covered with white felt, and the white hair on the sides of the thorax inclines towards felt. At 
Medicine Hat, too, a general change in tegmental colour, which must not be confounded with hair colour, is noticeable. Yellow bands and markings in the bare or nearly bare bees and wasps expand and multiply at the expense of black, and species, often of giant size, having red markings, especially on the first segment of the abdomen begin to appear, notably in the bee genera Anthidium, Epeolus and Nomada, and in the wasp genora, Vespa, Bembix, Microbembex, (yellow); Philanthus, Cerceris and Odynerus (red markings). Several species of Andrena from Toronto and Winnipeg regions have a red abdomen, but on the coasts and in the North the abdomen is always black. At Oxford, England, Andrena hattorfiana has a red abdomen, but at Dover the abdomen of this species is black.

Reduction of humidity acts in the same way as heat, but it appears to be less important. Indeed, in the present study, it can be demonstrated to be a negligible factor if rainfall be taken as its criterion. The summer rainfall of Dover and Victoria, B. C., is much less than that of Ottawa and Toronto. But humidity cannot be judged by rainfall which increases the relative humidity of soil and air in our region much less than heat reduces it.

Differences in winter temperature and rainfall, however, do not affect the characters to any extent. The same varieties are found on the mild and wet Pacific Coast as on the dry cold mountains. This is the more remarkable when when we remember that the distribution of the plants on which the bees feed is greatly affected by winter climate.

The same differences that are found between bees in a cool coastal summer climate and a warm interior one, are found between spring and summer flying bees in the same climate, and they are more marked in regions like Britain and the Pacific Coast where the spring is cool, than the interior of Canada where it warms up quickly. In England, and to a less extent in Ontario, the one species of Colletes that flies in the spring is larger and has a longer coat with feebler felt bands than the many species that fly in summer. Similarly, the early spring fying species of Andrena are large, have long coats and no felt bands; the summer flying species are generally smaller (except giant southern forms), have shorter coats with bate areas and frequently felt bands. At Ottawa, $A$. cockerelli which appears in spring before the snow has gone, has a longer, shaggier coat with less tendency to bare areas than any other species in Eastern Canada. Britain and the Pacific Coast have several large, robust, shaggy and long haired species of Anthophora appearing in early spring as well as shorter haired summer species, but the long haired spring species are not found on the prairie or in Eastern Canada.

Many of the differences noted are more shown in the females than in the males. Abdominal felt bands are always better developed in the females than in the males. Females of numerous species develop red tegumental markings, while the males remain black or yellow. In many species of Sphecodes the abdomen is black in the male and red in the female. In a large wasp found in Medicine Hat, Alta., Eucerceris gloriosa, the male is yellow and the female red. In Vespa carolina, a species found at Point Pelee, Ont., by Mr. Taverner, the queen has orange markings, while in the workers these markings are yellow. Can the reascn te that the female has a longer adult existence, or that the continuance of the species depends solely upon it after the male has died? 
Do the cool and warm conditions during the flying season work their opposing effects on the adult or the larva, or both? The female Halicti pass the winter as. adults, but live on until summer when they raise their brood. They have short coats and are of small size. The honey-bee raises its brood and passes the night in activity under the conditions of all seasons in an artificial heat provided by the colony. The European species of Andrena, A. gwynana Kirb. has two broods in the season. The spring-flying adults raised the previous summer hibernate as adults and are more robust with longer coats than the summer flying adults which are raised in the spring and have the slender, feeble appearance of the few species of Andrena found in the tropics.

Queens of the Italian bee that have been chilled in the pupa stage have the orange part of the integument darkened, and queens of Bombus lapidarius L. that slowly passed the pupa stage in the lowest temperature that could support life, had their black and red coat changed to brown.

How far the fact that British forms have a larger number of close allies on the Pacific Coast than in Eastern Canada is due to migration via Asia and how far to the action of similarity of climate cannot be estimated until our knowledge of Siberian forms, at present meagre, is greatly increased. The hairs clothing the body are of value to the bees for gathering pollen for which they are admirably adapted, being branched but unbranched in wasps. Their value for keeping the insect warm in chilly weather is apparently of secondary importance because wasps are almost as scantily clad in the north as in the south, and the parasitic bees are scantily clad. Bright colours and striking patterns, whether of coat or tegument, for instance in Bombus and many parasitic bees and many wasp genera, are usually of the warning kind and therefore are liable to regional convergence. In England, most of the species of Bombus have a white or a red tail. In Canada the only white or red-tailed species are in the western mountains and the north.

\section{CATOCALA LLALUME, A CORRECTION.}

BY G. H. FRENCH, CARBONDALE, ILLINOIS.

It may be unfortunate that Mr. Herman Strecker did not figure all of the new species that he described, for his descriptions, like those of some of the rest of us, were not always clearly drawn. Another unfortunate thing, for me, is that during a few years in which I was compelled to drop entomological work some of my material was lost, among which was $C$. ulalume. The specimens upon which were based my note in the Canadian Entomologist of January, 1919, page 16 , were Dr. Holland's C. carolina, and that is really a variety of C. febilis. This species is too small for C. ulalume.

Since writing the above-mentioned note I have seen material from several localities outside of Southern Illinois, containing a number of forms of C. lacrymosa and C. dejecta. One of these, I think from Kentucky, has the bluish sheen of $C$. dejecta, with no noticeable brown except a narrow subterminal shade of very dark brown, not noticeable except under the lens. This specimen had t. p. dentation of C. lacrymosa, but lacks the white along the t. a. and t. p. lines near the posterior margin of the wing that is so prominent in $C$. lacrymosa. The whole wing is pretty evenly dusted with black atoms.

June, 1919 